\section{NEWS and VIEWS \\ Chief of the Royal Naval Scientific Service: Dr. H. F. Willis}

DR. H. F. WILrIs, superintendent of the Admiralty Research Laboratory, 'Teddington, has been appointed chief of the Royal Naval Scientific Service, in succession to Mr. W. R. J. Cook (see Nature, 166, 135 ; 1950), who has become deputy director of the Atomic Weapons Research Establishment, Aldermaston. Dr. Willis, who is forty-five, is a graduate of University College, Cardiff, where he obtained first-class honours in mathematics in 1930 and physics in 1931. In the following year he gained the M.Sc. degree for research on relativity, and he became a Fellow of the University of Wales in 1933. He spent the next two years at Trinity College, Cambridge, engaged on experimental research into the optical properties of molecules, and for this work was awarded the Ph.D. degree. In 1935 he joined the British Cotton Industry Research Association and carried out fundamental research on the diffusion of dye-stuffs into cellulose fibres. These early researches were described in papers published in the Philosophical Magazine and in the Proceedings of the Royal Society and of the Faraday Society. Dr. Willis entered Admiralty service in 1938, and until 1945 was engaged on underwater acoustics research in the anti-submarine experimental group, where he served with notable success. He was then transferred to the Admiralty Research Laboratory, and until 1953 was leader of the group concerned with problems in electromagnetics and underwater ballistics. He was promoted to the rank of deputy chief scientific officer in January 1950, and became superintendent of the Admiralty Research Laboratory in 1953. 'The versatility and originality displayed by Dr. Willis in his own researches, and the skill which he has since shown in organizing and directing the work of a large establishment, augurs well for the Royal Naval Scientific Service in the increasingly important part which it is being called upon to play in naval affairs.

The French Canadian Association for the Advancement of Science : Dr. L. Marion, M.B.E.

Dr. Lx́o Marion, director of the Division of Pure Chemistry of the National Research Council of Canada, has been elected president for 1954-55 of the French Canadian Association for the Advancement of Science. He has also been awarded an honorary D.Sc. by Laval University, Quebec. Dr. Marion, who is fifty-five, is a graduate of Queen's University, Kingston, and a Ph.D. of McGill University, Montreal. Joining the National Research Council in 1929, he became head of the Organic Chemistry Section in 1943, and four years later he took on the added responsibilities of editor-in-chief of the Canadian Journal of Research, a post which he still holds. In 1952 he became director of the Division of Pure Chemistry. Dr. Marion's research work has been concentrated on the alkaloids, and for his contributions in this field he was awarded in 1948 the gold Médaille Léo Parizeau of the French Canadian Association for the Advancement of Science. $\mathrm{He}$ was elected to the Royal Society of Canada in 1942 and was made an M.B.E. in 1946.

\section{British Participation in an International Atomic} Energy Agency

$I_{N}$ reply to a question in the House of Commons on November 16, Sir Winston Churchill stated that during the past seven years the United Kingdom had exported to forty-six countries more than sixteen thousand consignments of isotopes and, at the present rate of seven thousand consignments a year, is the world's largest exporter of isotopes. Both Canada and the United States are also important exporters. The Isotopes Advisory Service offers advice and assistance, and foreign students are accepted at the Isotopes Training School at Harwell. Sir Winston agreed that the United States has given a fine lead towards establishing an international atomic energy agency and that it will have a great effect on the international situation if the Soviet Union can see its way to co-operate fully along these lines. On the same day, the Minister of State, Mr. A. Nutting, told the United Nations Political Committee in New York that, following the allocation by the United States the provious day of $100 \mathrm{kgm}$. of fissionable material, the British Government is prepared to hold available as required $20 \mathrm{kgm}$. of fissionable material for use in atomic research reactors abroad. Mr. Nutting added that the British Government has not changed its views as to the objectives of the agency: these are to encourage world-wide research and development of peaceful uses of atomic energy; to arrange for nuclear materials to meet the needs of research, development and practical applications to medicine and other peaceful activities, including the eventual production of power; to foster the interchange of unclassified information; and to prepare for a time when the use of atomic energy for peace becomes the predominant and perhaps the exclusive use of atomic energy.

\section{Sucrose Synthesis in Tobacco Leaves}

The synthesis of radioactive sucrose by tobacco leaves from glucose and glucose-1-phosphate uniformly labelled with carbon-14 has been described by P. V. Vittorio, G. Krotkov and G. B. Reed (Canadian J. Bot., 32, No. 3, 369; 1954). The petioles of detached tobacco leaves were placed for six hours in solutions of labelled glucose and glucose-1-phosphate, and at the end of this time the leaves were extracted with boiling 80 per cent ethanol and the activities of their various carbohydrate fractions determined. The specific activities of both the glucose and fructose moieties of sucrose were found to be high and very close to one another, while that of the free fructose was low. From this the authors have concluded that the fructose component of sucrose is derived from the glucose introduced and not from the free fructose present in leaves. Low activity in starch observed in photosynthesizing leaves indicates preferential transformation of the glucose introduced into sucrose and not into starch. Moreover, respiration of labelled glucose ought to produce labelled carbon dioxide and, after a period of photosynthesis, labelled starch. The isolated starch contained only a small amount of activity, indicating that, in light, sugars were not utilized in respiration to any great extent. In darkness, however, sugars were so utilized, the carbon dioxide evolved being very radioactive. The authors conclude that the mechanism of sucrose synthesis in tobacco leaves must be different from that reported for Pseudomonas saccharophila.

\section{Proceedings of the Botanical Society of the British Isles}

Ir has been decided to replace the "Yearbook" of the Botanical Society of the British Isles by a new publication-the Proceedings, which is to appear 